\title{
Analysis of Passenger Commuter Train Services Surabaya - Sidoarjo
}

\author{
Dwiatmoko, H., ${ }^{1}$, Mudjanarko, S. W., ${ }^{2, *}$, Setiawan, M. I., ${ }^{2}$, Nabila ${ }^{1}$ \\ ${ }^{1}$ University of Mercu Buana Jakarta, ${ }^{2}$ University of Narotama Surabaya \\ hermanto.dwiatmoko@mercubuana.ac.id,sri.wiwoho@narotama.ac.id
}

\begin{abstract}
This study aims to determine the service level of the Surabaya - Sidoarjo commuter train which is part of the transportation service in the Gerbang Kertasusila area. Surabaya is the second-largest city in Indonesia as the center of regional government for East Java and is the center of activity for all sectors in the region. The high population density and the high value of land in Surabaya have resulted in people choosing to live in Gerbang Kertasusila areas, namely Gresik, Bangkalan, Kertosono, Surabaya, Sidoarjo, and Lamongan (Gerbang Kertasusila). This resulted in the high movement of commuters from the buffer area for activities in downtown Surabaya. In this study, the analysis was carried out regarding the Minister of Transportation Regulation number 63 the year 2019 concerning Minimum Service Standards for Passenger Train Transportation. The research methodology used is Importance Performance Analysis by distributing questionnaires to commuter train users across Surabaya - Sidoarjo to find out people's opinions about train transportation services operated by PT. Kereta Api Indonesia. The results of the study can identify the level of service at the station and on the train, both those that are a priority to be improved and those that must be maintained.
\end{abstract}

Keywords: Commuter Train, Gerbang Kertasusila, importance performance analysis, standard of minimum services

\section{INTRODUCTION}

Transportation in Indonesia plays a very important role in the joints of people's lives. Along with the times, transportation technology has progressed quite rapidly. This is beneficial for the community to obtain an efficient mode of mass transportation. Surabaya is the second largest city in Indonesia as the center of regional government for East Java and is the center of activity for all sectors in the region. The high population density and the high value of land in Surabaya have resulted in people choosing to live in Gerbang Kertasusila areas, namely Gresik, Bangkalan, Kertosono, Surabaya, Sidoarjo and Lamongan (Gerbang Kertasusila). This resulted in the high movement of commuters from the buffer area for activities in downtown Surabaya.

PT. Kereta Api Indonesia (Pesereo) provides the Surabaya - Sidoarjo Commute.Train to accommodate commuter movements to and from the buffer cities of Surabaya. The Surabaya - Sidoarjo Commuter Train has been operating since 2004. The commuter train crosses the Surabaya Kota Surabaya Gubeng - Wonokromo - Gedangan - Sidoarjo - Tanggulangin - Porong - Bangil station. This mass transportation is in great demand by commuters because of its advantages, namely that it can carry passengers in large capacities, has its own lane so that it is avoided from congestion, and has a fast travel time.

Along with the rate of population growth in the Surabaya City buffer area, the movement of the Surabaya - Sidoarjo commuter train users have increased. The increase in movement was not accompanied by an increase in train facilities in operation, which resulted in complaints for commuters using train. Some of the factors that influence commuters' complaints are insufficient train capacity and 
train departures that are often not on schedule.

To make the commuter train the main transportation, the service factor must get attention. Service is a top priority that is used as a benchmark in competitiveness and facilities excellence and is a factor that affects the services provided by the company. PT. Kereta Api Indonesia is required to continue to improve in an effort to improve its services to the community and improve its operational system in order to produce maximum satisfaction for service users or customers. Therefore, this research is important to do to measure the level of satisfaction and expectations of service users with the Surabaya - Sidoarjo Commuter Train service.

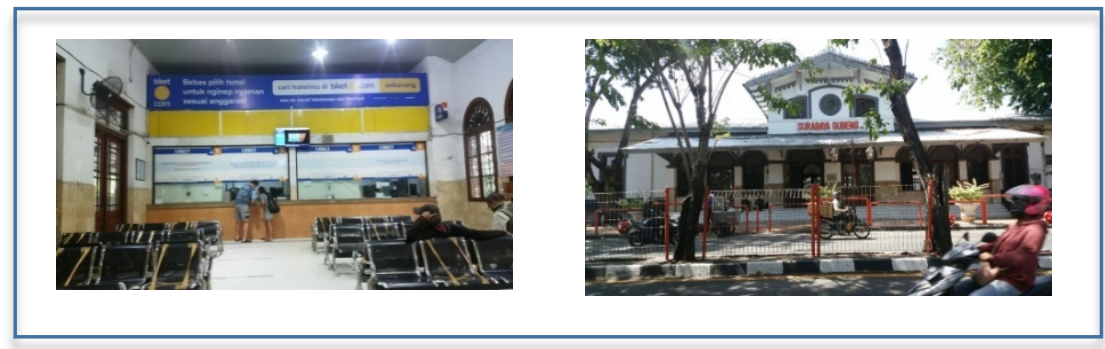

Fig 1. Gubeng Train Station Surabaya

\section{LITERATURE REVIEW}

Transportation is the activity of moving goods (cargo) and passengers from one place to another. In transportation, there are two most important elements, namely moving/moving and physically changing the place of goods and passengers to other places. Transportation is said to be good if the travel time is fast enough and there are no accidents, the frequency of service is sufficient, and the safety is free from the possibility of accidents and comfortable service conditions. The factors that become a component of transportation to achieve ideal conditions are the conditions of infrastructure and network systems and conditions of facilities.

The mode of transportation is very influential in supporting fast, safe, and integrated traffic movements. Transportation means are flexible, that is, develop according to the times and are adapted to the needs of consumers, however the determination of the type of transportation mode chosen must be appropriate to prevent traffic jams, waste of energy and space, and air pollution. Therefore, appropriate policies and handling are needed to minimize these undesirable factors.

The rail transportation mode has advantages over the road transportation, including a larger transport capacity, energy-efficient use, and low air pollution. Rail-based urban transportation can provide benefits to a city, for example, a large carrying capacity so that it can move passengers from road transport to rail. In the end, it will reduce congestion, road accidents, road damage, and reduce air pollution in cities. In providing services to commuter transport service users, a minimum service standard has been established through the regulation of the Minister of Transportation. Minimum Service Standards (SPM) are the minimum service measures that must be met by service providers in providing services to service users which is a reference for railway infrastructure operators operating train stations in providing services to service users, which must be equipped with benchmarks used as service delivery guidelines and service quality assessment references as obligations and promises of service providers to the public in the framework of quality, fast, easy, affordable and scalable services. There are two types of minimum service standards, namely the minimum service standards at stations and the service standards on the train.

\section{a. Minimum Service Standards at Stations}

In general, services at stations include clear and easy-to-read information regarding the appearance of the station and audio heard by service users; Passenger service facilities; Counter; The waiting room; Boarding room; Worship place; Nursing room for mothers; Toilet; Easy 
passenger boarding / disembarking facilities; persons with disabilities; health and safety and security facilities.

\section{b. Minimum Service Standards on the Train}

In general, services on the train include the availability of doors; window; a seat with a fixed construction that has a back; in-train lighting; air circulation regulator; luggage rack; standing passenger grip facilities; station information to be stopped/skipped sequentially; special facilities and conveniences for persons with disabilities; pregnant women, the sick, and the elderly; medical facility; facilities and security; information on safety and evacuation instructions in an emergency; train name and train serial number; information on train travel disruptions and the accuracy of train schedules.

\section{Importance Performance Analysis}

Importance Performance Analysis (IPA) is an analysis technique introduced by John A. Martilla and John C. James in 1977, which is used to identify what important performance factors an organization must show in meeting the satisfaction of their service users (consumers). In this method it is necessary to measure the suitability level to find out how much the customer is satisfied with the company's performance, and how much the service provider understands what the customer wants for the service they provide. This analysis is intended to get user importance to service attributes. In principle, IPA combines dimensional measurements to the expectations and importance two grids, then both dimensions were plotted into it. Importance value is plotted as the vertical axis while the expected value as a diagonal axis by using the mean value contained inimportance and expectation dimension as the center line cutting. The diagram consists of four- quadrant that shows level of importance to service attributes. IPA is used to get the importance of customer to service attributes. The level of importance is described in the importance diagram that is divided into four quadrants (figure 1) with description as follows,

a. Quadrant A, the area that contains the attributes are considered important by customers but not as expected (levels of customer satisfaction are still very low). In this area the management institution performs improvements continuously in order to increase performance in this quadrant.

b. Quadrant B, the area that contains the attributes is considered important by customers and the attributes are assumed in accordance with the perceived so the level of satisfaction is high.

c. Quadrant C, the area that is contains attributes are considered less important by the customer and in fact have less special performance.

d. Quadrant D, the area that contains the attributes are considered less important by the customer and assumed excessively.

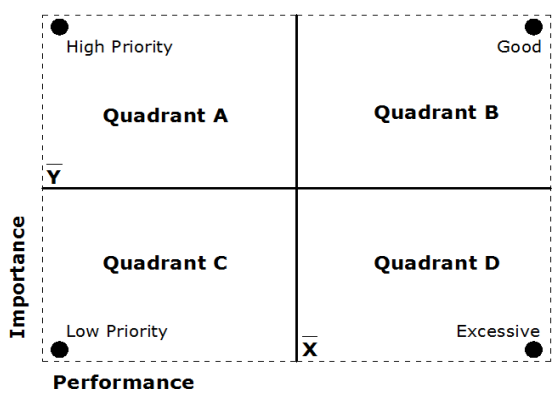

Fig 2. Importance Classification Diagram

\section{RESEARCH METHODOLOGY}

This research methodology uses quantitative research. The data used in this study is a combination of qualitative and quantitative data obtained through a survey using a questionnaire. Meanwhile, the instrument used in this questionnaire refers to the results of research conducted by 
Parasuraman et.al (1988), namely by using the Servqual method.

\section{Research Location}

In order for the research to be carried out evenly, several points were determined to represent the whole. The observation points are determined based on areas deemed appropriate but still on the route of the Gerbang Kertasusila commuter train. The research location was carried out at two stations, namely Sidoarjo and Surabaya Gubeng Stations. At the station, primary data was collected with the help of a questionnaire. The questionnaire was distributed to commuter train users on the Sidoarjo Surabaya Gubeng route and through online questionnaires.

\section{Data collection technique}

In this study, the data collection technique used a quota sampling method where the respondents were users of the Gerbang Kertasusila commuter train. The quota sampling method is a data collection technique by taking samples freely from a population that has certain characteristics to the desired quota. The data used is in the form of primary data which is a questionnaire distributed to respondents.

\section{Population and Sample}

The method used to determine the number of respondents in this study is to use the method Roscoe (1975) in Uma Sekaran (1992: 252) provides guidelines for determining the number of samples. In this study, the sample size was 100 respondents.

\section{Validity Testing}

Validity is intended to state the extent to which the data contained in a questionnaire will measure what you want to measure. The validity test was carried out by using the Pearson method or the Product Moment Correlation Method, namely by correlating the item scores on the questionnaire with the total score. A questionnaire is said to be valid if the questions on a questionnaire are able to measure what is and should be measured.

\section{Reliability Testing}

Reliability is the extent to which a meter is error free or reliable and trustworthy. Reliable instruments can be used safely in different times and conditions or remain consistent when used in two or more measurements to measure the same symptoms, while temporary and situational factors have no effect (Cooper \& Emory; 1996).

\section{RESULTS}

\section{Respondent Data}

Based on the results of the analysis of respondent data, it can be concluded that the Commuter Train Gerbang Kertasusila has uniform data, namely that it is more attractive to women, aged between 20-30 years, with jobs as private employees and the frequency of using train is between 10-14 times one week.

\section{Data Analysis}

Analysis of the data used in this study is the descriptive statistical analysis available in the SPSS program. Descriptive statistics are concerned with the collection and ranking of data. Descriptive statistics describe the sample characters used in this study. As a follow-up to the questionnaire data processing, to find out the condition of the Gerbang Kertasusila commuter train service, the results of data analysis were grouped into 4 quadrants according to the Cartesian Important Performance Analysis diagram. 


\section{Passenger Service in the Station}

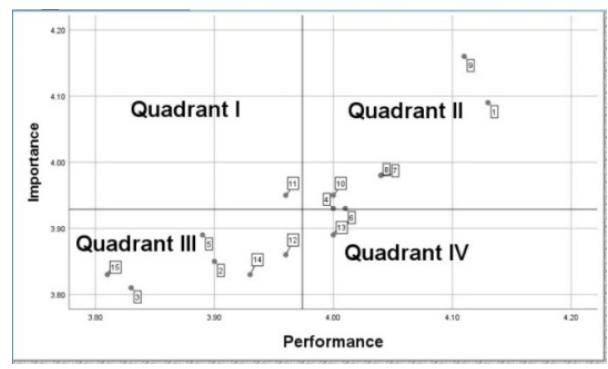

Fig. 3. Cartesian Diagram of Passenger Services in the Station

Service attributes found in quadrant I mean that services that must be improved are toilet cleanliness, services that must be maintained include visible and affordable station safety facilities, availability of CCTV, availability of security officers, sufficient lighting, availability of ticket sales counters, operating schedules, train arrival schedule, clean and comfortable waiting area.

\section{Passenger Service on the Train}

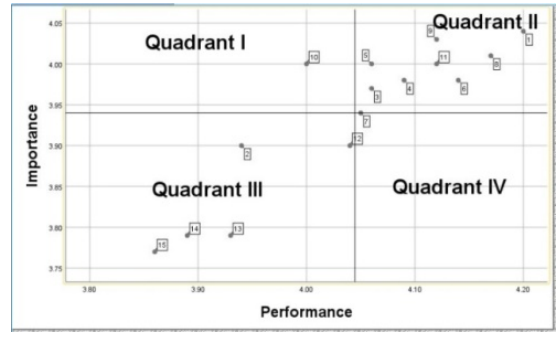

Fig. 4. Cartesian Diagram of Passenger Services on the Train

The service attribute contained in quadrant I means that services that must be improved are the availability of information on train travel disruptions for services that must be maintained including the availability of information and safety facilities on the train, security officers, train travel information, the availability of comfortable seats; availability of air conditioning and cleanliness of the train

\section{CONCLUSION}

From the results of the research that has been done, it can be concluded that:

a. Surabaya Gubeng Station and Sidoarjo Station which are used to serve the Gerbang Kertasusila commuter transportation, especially for the Sidoarjo - Surabaya Gubeng route, have equipped facilities for commuter passenger services, including facilities, safety, security, comfort, reliability and equality, however, the results of the research it can be identified several services that need to be improved, namely the cleanliness of the toilet, while the services that must be maintained include:

1) Easy to reach safety facilities;

2) Availability of CCTV;

3) Availability of security officers and cleaners;

4) Availability of lighting lamps;

5) Availability of ticket sales counters;

6) Availability of operating schedules and network maps;

7) The reception area is clean and comfortable. 
b. Services on commuter trains have been undertaken by train operators, namely PT. Kereta Api Indonesia $(\mathrm{KAI})$, however the diesel rail train currently operated is old even though it is still reliable, but there are several things that need to be improved, namely:

1) Availability of information and safety facilities;

2) Officers in uniform that are easily visible;

3) Travel information on the train;

4) Availability of seat on the train;

5) Availability of air regulator (AC);

6) Cleanliness in the train.

Acknowledgments: The author of this paper would like to thank the Dean of the Engineering Faculty at University of Mercu Buana and the Rector of Narotama University for the opportunity given to carry out this study.

\section{REFERENCES}

A. Parasuraman, Valarie A. Zeithaml, and Leonard L. Berry. (1988). "SERVQUAL: A Multiple-Item Scale for Measuring Consumer Perceptions of Service Quality". Journal of Retailing Volume 64 Number 1 Spring 1988

Afif Ahmad Afiyat, Bietrix Rosalina, M. Zainul Arifin, dan Achmad Wicaksono. (2015). Kajian Kinerja Pelayanan Dan Tarif Kereta Api Eksekutif Jurusan Malang - Jakarta (Studi Kasus Kereta Api Eksekutif Bima). Malang : Universitas Brawijaya.

Dwiatmoko, Hermanto. 2018. Perencanaan Pembangunan Transportasi Kereta Api. Jakarta : Prenada Media.

Elfarischa Deasy Pramyastiwi, Imam Hardjanto, dan Abdullah Said. 2012. Perkembangan Kualitas Pelayanan Perkeretaapian Sebagai Angkutan Publik Dalam Rangka Mewujudkan Transportasi Berkelanjutan

(Studi Pada PT. Kereta Api Indonesia Daerah Operasi 8 Surabaya). Malang : Universitas Brawijaya.

Hidayati Nurul. (2012). Pelayanan Terhadap Kepuasan Penumpang Ka Lokal Rute Cikampek - Pasarsenen pada PT. Kereta Api Indonesia (Persero). Jakarta : Universitas Mercubuana.

John A. Martilla and John C. James. (1977) "Importance-Performance Analysis". Journal of Marketing, January, 1977

Kamelya Rizka. (2017). Analisis Kepuasan Pelanggan Terhadap Kualitas Pelayanan Kereta Rel Listrik (KRL) Commuter Line Rute Kota - Tanjung Priok Dalam Upaya Meningkatkan Kinerja Transportasi Berbasis Kereta Api. Jakarta : Universitas Mercubuana.

Mohd Zalina Ali, dkk. 2009. Importance Performance Analysis and Customer Statisfaction Index for Express Bus Service. Selangor : Universitas Selangor.

Pelani Afrianto. (2015). Analisis Kualitas Layanan PT. KAl Terhadap Kepuasan Pengguna Jasa Kereta Commuterline Jabodetabek Di Stasiun Manggarai Jakarta. Bogor : Institut Pertanian Bogor.

Republik Indonesia. 2007. Perkeretaapian. Undang - Undang No. 23 Tahun 2007. Lembaran Negara Republik Indonesia Tahun 2007, Nomor 65. Sekretariat Kabinet RI. Jakarta.

Syawaludin Rizqi Ahmad. (2016). Analisa Kepuasan Penumpang Terhadap Pelayanan Kereta Rel Listrik (KRL) Commuter Line Rute Duri -Tangerang. Jakarta : Universitas Mercubuana.

Yusnia Utari Putri. (2018). Analisis Tingkat Kinerja Pelayanan Angkutan Umum Kereta Rel Listrik Ditinjau Dari Sudut Operasional dan Kepuasan Penumpang (studi kasus commuter line rute Jakarta Kota - Cikarang). Jakarta : Universitas Mercubuana.

Zeithaml, A., Valarie, A., Parasuraman, Leonard, L.B. 2000. Delivering Quality Service: Balancing Customer Perceptions And Expectations. New York: The Free Press, Division Of Macmillan Inc.

(C) 2020 by the authors. Submitted for possible open access publication under the terms and conditions of the Creative Commons Attribution (CC BY SA) license (https://creativecommons.org/licenses/by-sa/3.0/). 